\title{
Population structure and genetic diversity in natural populations of Theobroma speciosum Willd. Ex Spreng (Malvaceae)
}

\author{
L.D. Giustina ${ }^{1}$, L.N. Luz ${ }^{2}$, F.S. Vieira ${ }^{1}$, F.S. Rossi ${ }^{1}$, \\ C.R.A. Soares-Lopes ${ }^{1}$, T.N.S. Pereira ${ }^{2}$ and A.A.B. Rossi ${ }^{1}$
}

${ }^{1}$ Faculdade de Ciências Biológicas e Agrárias, Campus Universitário de Alta Floresta, Universidade do Estado de Mato Grosso, Alta Floresta, MT, Brasil ${ }^{2}$ Laboratório de Melhoramento Genético Vegetal, Centro de Ciências e Tecnologias Agropecuárias, Universidade Estadual do Norte Fluminense Darcy Ribeiro, Campos dos Goytacazes, RJ, Brasil

Corresponding author: A.A.B. Rossi

E-mail: anabanrossi@gmail.com

Genet. Mol. Res. 13 (2): 3510-3519 (2014)

Received May 22, 2013

Accepted October 3, 2013

Published February 14, 2014

DOI http://dx.doi.org/10.4238/2014.February.14.5

\begin{abstract}
The genus Theobroma found in the Amazon region is composed of 22 species, including Theobroma speciosum, better known as cacauí. These species are constantly threatened by forest fragmentation caused by human activities and require conservation strategies and management aimed at preserving them in their natural environments. The main objective of this study was to analyze the population structure and genetic diversity within and between natural populations of $T$. speciosum by using ISSR molecular markers to understand the population structure of the species. Four natural populations belonging to the Amazon rainforest (BAC, CRO, FLA, and PNA), located in the State of Mato Grosso, were selected. Amplification reactions were performed using 15 ISSR primers. A total of 101 loci
\end{abstract}


were found, of which $54.46 \%$ were polymorphic at the species level. The BAC population showed higher genetic diversity $(\mathrm{H}=0.095$ and $\mathrm{I}=0.144)$ and higher percentage of polymorphism $(28.71 \%)$. The populations showed an $F_{\mathrm{ST}}$ value of 0.604 , indicating marked genetic differentiation. The highest genetic variation was found between populations. Gene flow was low between populations, indicating genetic isolation between populations.

Key words: Cacauí; Biodiversity; Genetic variability; Amazon; ISSR

\section{INTRODUCTION}

The Amazon rainforest has one of the highest rates of biodiversity in the world (Lima, 2002). It is a gene pool for many animal and plant species and an endless source of variability for endemic species, including Theobroma sp, a leading genus of the family Malvaceae (Alverson et al., 1999; Whitlock et al., 2001), previously called Sterculiaceae. Theobroma $\mathrm{sp}$ is distributed in the tropical rainforests of the Southern hemisphere, from Mexico to the Southern Amazon rainforest. It consists of 22 species (Cuatrecasas, 1964), but only 4 of them have been commercially exploited, including cacao, Theobroma cacao L. and cupuaçu, Theobroma grandiflorum Willd. ex Spreng. K. Schum; cupuí, Theobroma subincana Mart and cacauí, Theobroma speciosum Willd. ex Spreng are the wild relatives of cupuaçu and cacao, respectively.

T. speciosum Willd. ex Spreng, the cacauí, is still little known beyond its traditional areas of occurrence. It has great potential for producing derivatives for human consumption and can be found throughout the Amazon region and among the species of the genus. The production of fat content, an essential element for sweets and derivatives, is the second highest in cacauí after cocoa (Silva et al., 2004). Regarding morphology, T. speciosum ranges from 8-14 $\mathrm{m}$ in height and has a long stem, thin and narrow canopy, with 20-40 $\mathrm{cm}$ long and 7-17 $\mathrm{cm}$ wide leaves. The almonds of its berry-type fruit are yellowish when ripe and can be used to produce soft drinks and chocolates. Its exuberant inflorescence along the stem can be successfully used for landscaping (Lorenzi, 1998).

Natural populations are subject to many environmental effects that may affect their rate of retention in the environment of origin, including the destruction of their habitat and consequent fragmentation of populations (Matocq and Villablanca, 2001). The consequences of these interventions in the spatial distribution of species might trigger genetic processes that affect gene frequencies of populations, including dispersive processes, gene oscillation, and founder effect. These genetic processes strengthen systematic processes, migration, mutation, and selection, which are already in progress in the population.

Mechanisms for understanding population dynamics in natural populations of plants are extremely important to preserve genetic heritage, since these contain the knowledge about the reproductive behavior and the effects of environmental interference on populations. Gene flow and the degree of differentiation between populations obtained by molecular-genetic analyses, compared between and within natural populations, provide better understanding of how selection occurs according to adaptation in isolated populations, besides providing a measurement to quantify the genetic variability in the population as a whole (Bekessy et al., 2002; Estopa et al., 2006). 
Knowledge of the genetic structure of natural populations is also extremely important for developing strategies for the conservation of plant genetic resources and the maintenance of genetic variability of populations. However, this is more effective when performed using genetic information, such as that obtained from genetic markers, since they are not affected by the environment. The determination of genetic diversity and structure of natural populations has been recognized as not only the creation of in situ and ex situ conservation strategies (Holsinger and Gottlieb, 1991; Morden and Loeffler, 1999), but also a way to promote rational economic exploitation of plant genetic resources (Holsinger and Gottlieb, 1991; Reis, 1996).

DNA markers are among the main tools for the genetic analysis of populations, since they have several advantages, including the fact that they are not affected by the environment and are not dependent on the plant life stage. They are also important for breeding programs (Zietkiewicz et al., 1994). The inter-simple sequence repeat (ISSR) markers have been widely used in studies on genetic diversity and variability of wild populations. They are better than the others since they do not require prior information of the DNA sequence, have low development costs, and have high transferability to other plant species, and generate a greater number of polymorphic fragments (Barth et al., 2002; Brandão et al., 2011). ISSR markers have been found to be efficient in several studies on genetic population variability (Cidade et al., 2009; Rossi et. al., 2009; Brandão et al., 2011).

This study aimed to evaluate the population structure and genetic diversity between and within natural populations of T. speciosum, Cacauí, from the Amazon rainforest in the northern State of Mato Grosso by using ISSR markers in order to provide the basic knowledge that can be applied for the conservation and breeding of the species.

\section{MATERIAL AND METHODS}

\section{Collection of genetic material and DNA extraction}

Four areas were selected for the collection of plant material, on the basis of the natural occurrence of the species in the Amazon forest. Each selected area was considered one population. Within each population, 18-20 geographically distant individuals were selected. The areas sampled were the following: Bacaerí farm (BAC), Cristalino Reserve (CRO), Floresta Amazônica Hotel (FLA), and Mundo Novo Community (PNA). The populations were named after their respective sampling sites (Table 1).

Table 1. Name of populations with their respective code, number of individuals (N) and geographic location of
the populations studied.
\begin{tabular}{llccc}
\hline Populations & Code & N & Latitude (S)* & Longitude (W)* \\
\hline Fazenda Bacaerí & BAC & 20 & $9^{\circ} 56^{\prime} 49.01^{\prime \prime}$ & $56^{\circ} 55^{\prime} 01.16^{\prime \prime}$ \\
Reserva do Cristalino & CRO & 20 & $9^{\circ} 35^{\prime} 52.95^{\prime \prime}$ & $55^{\circ} 55^{\prime} 54.53^{\prime \prime}$ \\
Floresta Amazônica Hotel & FLA & 21 & $9^{\circ} 52^{\prime} 44.68^{\prime \prime}$ & $56^{\circ} 05^{\prime} 59.16^{\prime \prime}$ \\
Comunidade Mundo Novo & PNA & 18 & $9^{\circ} 48^{\prime} 07.00^{\prime \prime}$ & $55^{\circ} 55^{\prime} 29.06^{\prime \prime}$ \\
Total & & & \\
\hline
\end{tabular}

*Location obtained through Google Earth program.

The leaf material was collected in the intermediate stage of maturation. While still in the field, the leaves were placed in a plastic bag containing silica gel and were subsequent- 
ly stored at $-20^{\circ} \mathrm{C}$ at the Laboratory of Genetics, University Campus of Alta Floresta, MT. The extraction was performed according to the CTAB method described by Doyle and Doyle (1987), with modifications suggested by Faleiro et al. (2002). Briefly, the following composition was used: $5 \%$ CTAB (100 mM Tris-HCl, $\mathrm{pH} 8.0 ; 1.4 \mathrm{M}$ sodium chloride, $20 \mathrm{mM}$ EDTA), $2 \%$ polyvinyl pyrrolidone, $2 \%$ mercaptoethanol, and $3.5 \mu \mathrm{L}$ Proteinase $\mathrm{K}(100 \mu \mathrm{g} / \mathrm{mL})$.

The extracted DNA was quantified by comparing the size with a DNA of known molecular mass, by electrophoresis on $0.8 \%$ agarose gel stained with ethidium bromide (Ferreira and Grattapaglia, 1998). The gels were analyzed using a transluminator under ultraviolet light and photographed. After quantification, the samples of the extracted DNA were diluted in autoclaved distilled water and standardized to a concentration of $20 \mathrm{ng} / \mu \mathrm{L}$ genomic DNA.

\section{PCR and data analysis}

Thirty-four ISSR primers were tested. The amplification reaction was conducted using 15 primers previously selected (Table 2). The reactions contained a total volume of $20 \mu \mathrm{L}$. The amplification program was established as described by Charters and Wilkinson (2000): one initial cycle of denaturation at $94^{\circ} \mathrm{C}$ for $5 \mathrm{~min}$, followed by 30 cycles of $94^{\circ} \mathrm{C}$ for $1 \mathrm{~min}$, annealing at $45-60^{\circ} \mathrm{C}$ (depending on the primer used) for $2 \mathrm{~min}$, extension at $72^{\circ} \mathrm{C}$ for $30 \mathrm{~s}$, and one final extension cycle of $72^{\circ} \mathrm{C}$ for $5 \mathrm{~min}$.

\begin{tabular}{|c|c|c|}
\hline Primer & Sequences $\left(5^{\prime} \rightarrow 3^{\prime}\right)$ & $\operatorname{Tm}\left({ }^{\circ} \mathrm{C}\right)$ \\
\hline UBC 807 & AGA GAG AGA GAG AGA GT & 47 \\
\hline UBC 808 & GAG AGA GAG AGA GAG AYC & 48.8 \\
\hline UBC 812 & GAG AGA GAG AGA GAG AA & 47 \\
\hline UBC 826 & ACA CAC ACA CAC ACA CC & 53 \\
\hline UBC 827 & ACA CAC ACA CAC ACA CG & 53 \\
\hline UBC 834 & AGA GAG AGA GAG AGA GYT & 49 \\
\hline UBC 835 & AGA GAG AGA GAG AGA GYC & 50.2 \\
\hline UBC 841 & GAG AGA GAG AGA GAG AYC & 50 \\
\hline UBC 842 & GAG AGA GAG AGA GAG AYG & 49 \\
\hline UBC 844 & CTC TCT CTC TCT CTC TRC & 48.6 \\
\hline UBC 855 & ACA CAC ACA CAC ACA CYT & 44 \\
\hline UBC 856 & ACA CAC ACA CAC ACA CYA & 50 \\
\hline UBC 857 & ACA CAC ACA CAC ACA CYG & 50 \\
\hline UBC 861 & ACC ACCACCACCACCACC & 59 \\
\hline UBC 889 & DBD ACA CAC ACA CAC AC & 51.4 \\
\hline
\end{tabular}

$\mathrm{Y}=\mathrm{C}$ or $\mathrm{T} ; \mathrm{R}=\mathrm{A}$ or $\mathrm{G} ; \mathrm{V}=\mathrm{A}, \mathrm{C}$ or $\mathrm{G} ; \mathrm{H}=\mathrm{A}, \mathrm{C}$ or $\mathrm{T}$.

The amplification products were separated by electrophoresis on $1.5 \%$ agarose gel in $1 \mathrm{X}$ TBE running buffer at constant voltage of $85 \mathrm{~V}$ for $4 \mathrm{~h}$. The gel was stained using ethidium bromide $(0.6 \mathrm{ng} / \mathrm{mL})$. The sizes of the amplified fragments were estimated by comparison with the $100 \mathrm{bp}$ DNA Ladder molecular marker (Figure 1).

The amplification products were analyzed and encoded as binary characters: presence (1) or absence (0) of bands. The POPGENE 1.31 software system (Yeh et al., 1999) was used for analyzing the data of presence/absence matrix to estimate the diversity parameters. Gene identity and genetic distance between populations were calculated using the model presented in Nei (1978). Gene differentiation coefficient $\left(G_{\mathrm{ST}}\right)$ was estimated to determine the genetic structure across populations. The distribution of genetic variability within and between popu- 
lations was analyzed by analysis of molecular variance (AMOVA), according to Excoffier et al. (1992), by using the ARLEQUIN 3.01 software system (Excoffier et al., 2006). The $F_{\mathrm{ST}}$ peer-to-peer value matrix of the populations was generated by using the ARLEQUIN 3.01 software system (Excoffier et al., 2006) to build phenograms representative of the genetic distances between populations. This matrix was imported to MEGA 3.1 (Kumar et al., 2004) for the construction of a dendrogram by using unweighted pair group method with arithmetic mean (UPGMA).

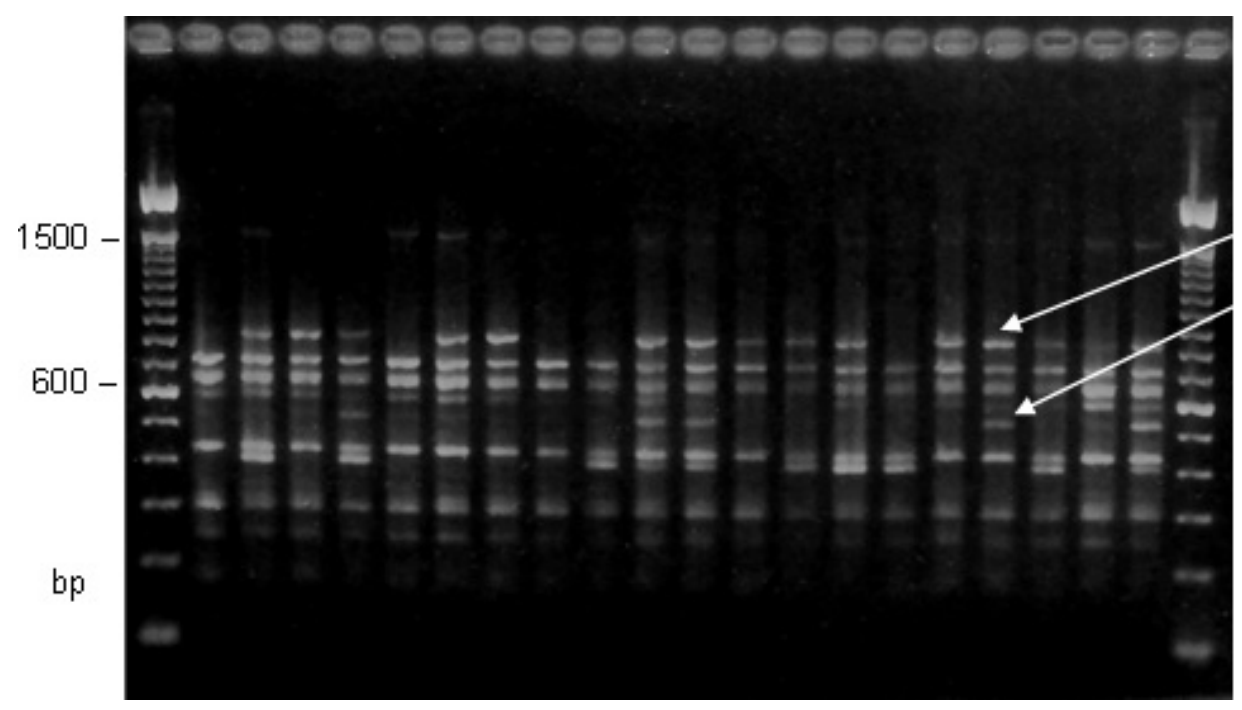

Figure 1. Standard amplification using primer 842 in 20 individuals of the population CRO.

\section{RESULTS AND DISCUSSION}

In all, 101 fragments were generated by ISSR markers in T. speciosum. Of these fragments, $54.46 \%$ were polymorphic. Figure 1 shows the standard of amplification of primer 842 in the individuals of the CRO population. The BAC population presented 29 polymorphic bands, while PNA, CRO, and FLA populations produced 27, 19, and 18 polymorphic bands, respectively. Populations BAC and PNA showed higher genetic diversity and greater percentage of polymorphism than the other populations. The value of genetic diversity at the species level obtained by Nei's diversity (H) was 0.167 , while the Shannon's diversity index (I) was 0.254 (Table 3).

Table 3. Genetic diversity within populations of Theobroma speciosum.
\begin{tabular}{lcccc} 
Population & $\mathrm{N}$ & $\mathrm{P}(\%)$ & $\mathrm{H}$ & $\mathrm{I}$ \\
\hline BAC & 20 & 28.71 & 0.095 & 0.144 \\
CRO & 20 & 18.81 & 0.069 & 0.103 \\
FLA & 21 & 17.82 & 0.051 & 0.079 \\
PNA & 18 & 26.73 & 0.091 & 0.135 \\
Mean & & 0.076 & 0.115 \\
Species level & 54 & 54.46 & 0.167 & 0.254
\end{tabular}

$\mathrm{N}=$ sample size; $\mathrm{P}=\%$ polymorphism; $\mathrm{H}=$ Nei's genetic diversity; $\mathrm{I}=$ gene diversity index of Shannon. For abbreviations, see Table 1 . 
The ISSR molecular markers could detect polymorphism in the populations and were possibly reproducible for the species. Therefore, this is an efficient method to detect genetic variability within and between populations of T. speciosum. Some authors have reported the successful use of ISSR markers (Almeida et al., 2009; Rossi et al., 2009; Brandão et al., 2011). These markers are efficient, cost-effective, and generate large amount of information. $\mathrm{H}$ ranged between 0.051 (FLA) and 0.095 (BAC), while I ranged between 0.079 (FLA) and 0.1443 (BAC), with an average of $\mathrm{H}=0.167$ and $\mathrm{I}=0.254$ at the species level. Since I ranges from 0 to 1 , and the higher the proximity to 0 , the lower is the genetic variability of the population, these results indicate low diversity for the species.

For cacauí, T. speciosum, comparison of results is not possible because no records of genetic analysis of this species were found. However, studies on other species under the same conditions of this study may allow the understanding of the magnitudes of $\mathrm{H}$ and I presented here. Oliveira et al. (2008) reported high levels of diversity in populations of Dimorphandra mollis $(\mathrm{H}=0.303$ and $\mathrm{I}=0.460)$; similarly, Rossi (2007) showed high diversity in Mauritia flexuosa $(\mathrm{H}=0.206$ and $\mathrm{I}=0.308)$; Estopa et al. (2006) in natural populations $(\mathrm{H}=0.400$ and $\mathrm{I}=0.580)$ of Eremanthus erythropappus; and Batista et al. (2008) in Tibouchina papyrus $(\mathrm{H}=$ 0.230 and $\mathrm{I}=0340$ ). These studies were also conducted in natural populations by using ISSR primers. The results of these studies are comparatively similar to those obtained in this study. Nonetheless, the $\mathrm{H}$ and I values reported in those studies were higher than those obtained for T. speciosum, indicating low diversity for the species.

AMOVA (Table 4 ) indicated that $60.45 \%$ of the total variance occurred between populations, while $39.55 \%$ was attributed to variation within populations. There was significant genetic differentiation $(\mathrm{P}<0.000)$ between populations. These results suggest that most genetic differentiation is observed in the interpopulation component, i.e., individuals within a population are more similar to each other and may develop remarkable differentiation over the years. The same standard of distribution between populations was found by Silva et al. (2007), who reported high interpopulation genetic differentiation in populations of Oryza glumaepatula Steud. (Poaceae).

Table 4. Analysis of molecular variance (AMOVA) of the four populations of Theobroma speciosum studied
from 15 ISSR markers.
\begin{tabular}{lrccccc}
\hline Source of variation & d.f. & SS & CV & TV (\%) & P value \\
\hline Between populations & 3 & 131.000 & 3.77745 & 60.45 & $<0.000$ \\
Within populations & 75 & 185.329 & 2.47106 & 39.55 & \\
Total & 78 & 416.329 & 6.24850 & & \\
\hline
\end{tabular}

d.f. = degrees of freedom; $\mathrm{SS}=$ sum of squares; $\mathrm{CV}=$ coefficient of variation; $\mathrm{TV}=$ total variation; $\mathrm{P}=$ chances of a variance component greater than the observed values by chance. The probabilities were calculated using 1023 random permutations.

Deforestation and consequent reduction in the effective population size might lead to the fragmentation of populations, causing reproductive isolation. The data obtained in this study do not allow the inference about the level of endogamy in the populations studied, since dominant markers were used and the number of heterozygotes was not measured due to the lack of availability of co-dominant markers for the species. However, the results of AMOVA for variability within populations (39.55\%) suggest that the populations may tend to show endogamy, to a lesser extent than a population that is not fragmented. 
According to Hamrick (1982), the reproductive factor is important for the formation of the genetic structure of a population. In general, unlike allogamous species, autogamous species have low genetic diversity within populations and high genetic differentiation between populations (Hamrick and Godt, 1996). However, high genetic differentiation was found between populations in our study, which can be explained by the low gene flow $(0.40)$ between populations instead of the reproduction system itself, since, according to Figueira and Cascardo (2001), the genus Theobroma is an allogamous species. This low gene flow might result from the reduced number of pollinators, either due to environmental degradation or increased distance between populations caused by fragmentation.

The populations of $T$. speciosum analyzed in this study showed an $F_{\mathrm{ST}}$ value of 0.60 . According to Wright (1931), $F_{\mathrm{ST}}$ above 0.25 indicates high genetic differentiation. The estimated total heterozygosity (HT) was 0.172 , which indicates that the species has a reserve of genetic variability in these populations. The percentage of the total genetic divergence found between populations $\left(G_{\mathrm{ST}}\right)$ was 0.552 (Table 5). It was corroborated by the results of AMOVA.

Table 5. Genetic parameters of the Theobroma speciosum population.
\begin{tabular}{lcccc}
\hline HT & HS & $G_{\mathrm{ST}}$ & $\mathrm{Nm}$ \\
\hline Mean & 0.172 & 0.076 & 0.552 & 0.404 \\
Standard deviation & 0.037 & 0.011 & & \\
\hline HT = total heterozygosity; HS = average genetic diversity within populations; $G_{\mathrm{ST}}=$ genetic divergence between \\
populations; Nm = gene flow.
\end{tabular}

In small fragments, the isolation of populations of tree species reduces the number of reproductive individuals and the density of population and might affect genetic processes such as genetic drift, gene flow, selection, and reproduction system (Yang and Meerow, 1996; Wrigth, 2005). Between the study populations, the estimate of gene flow, or the number of migrants per generation was 0.404 (Table 5). According to Wright (1931), gene flow values below 1 indicate genetic isolation. This tendency toward isolation measured by gene flow $(0.404)$ reinforces the differentiation between populations $\left(F_{\mathrm{ST}}=0.60\right)$. These findings suggest that genetic isolation might be in progress in these populations.

The dendrogram representing genetic distances (Figure 2) showed that the populations BAC and CRO are the most genetically similar. The PNA population seemed to be the most genetically distant from the other populations. However, populations with higher genetic proximity are known to be the most geographically distant (Figure 3 and Table 6). These results are not completely explained by the gene flow (0.404) between populations. The most genetically similar populations were the most geographically distant (BAC and CRO), suggesting that the genetic structure is not a factor determined by geographic distance; nonetheless, these results are not conclusive. A larger sample of individuals in each population might clarify the relationship between gene flow and geographic distance between populations.

Taken together, our results showed that there is moderate genetic variability in natural populations of $T$. speciosum, and that the levels of genetic polymorphism maintained in this species might facilitate conservation practices, despite constant forest fragmentation. Bittencourt (2007) and Wright (2005) suggested that in situ conservation strategies for forest species is the best strategy to maintain the genetic integrity of populations. 


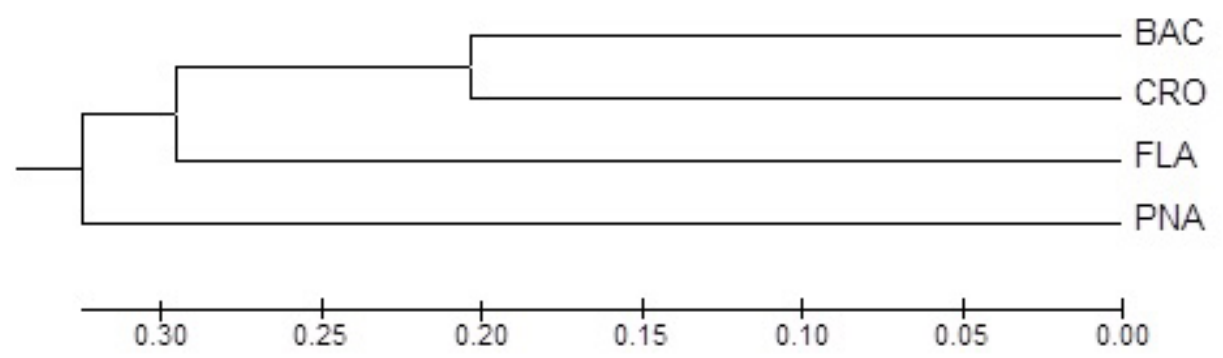

Figure 2. UPGMA dendrogram of four populations of Theobroma speciosum based on genetic diversity matrix. For abbreviations, see Table 1.

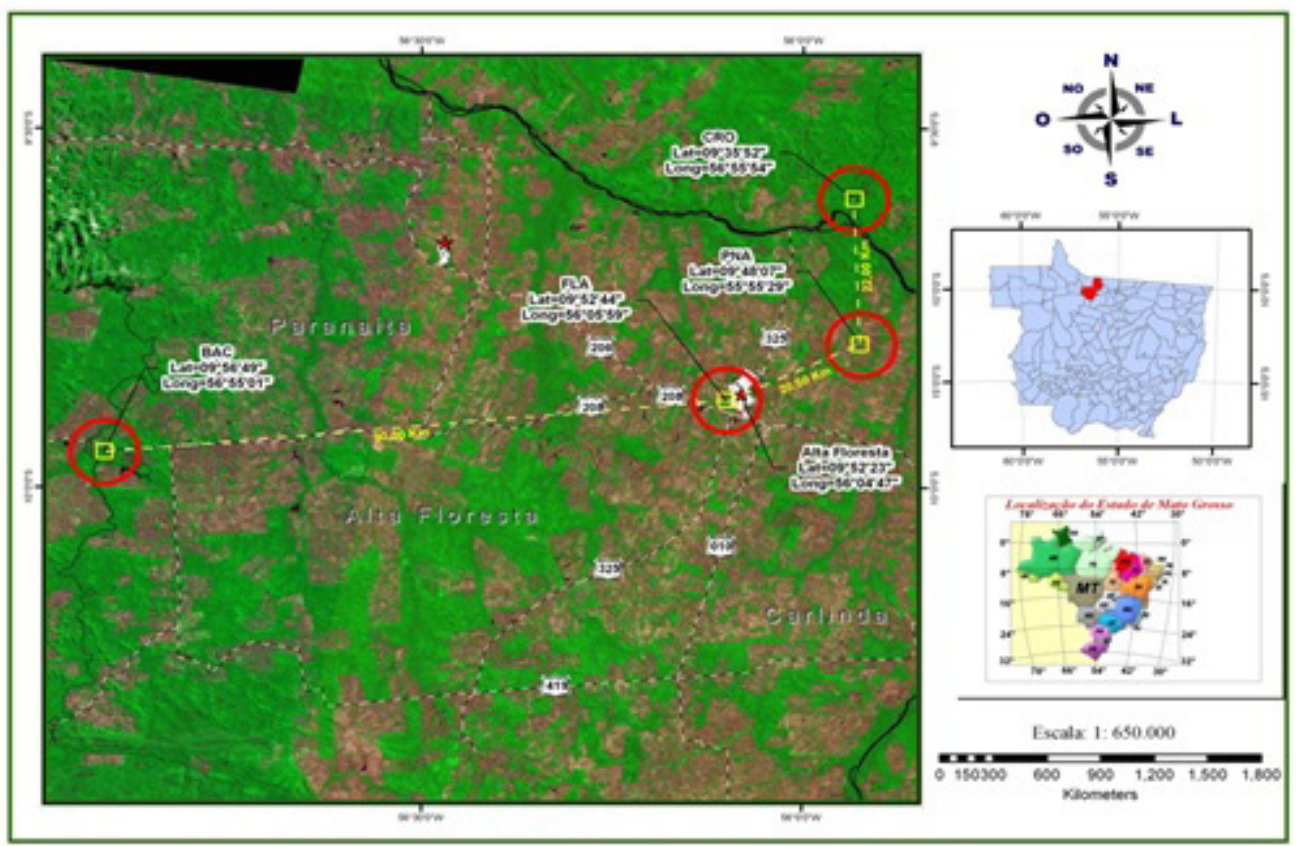

Figure 3. Geographical location of the four Theobroma speciosum populations analyzed in this study. The circles in red correspond to the populations studied. The image was obtained from the Land satellite, georeferenced in the Micro Station program and finished in ArcGis. For abbreviations, see Table 1.

Table 6. Geographical distance, genetic distance and genetic identity of Nei (1978) among four populations of Theobroma speciosum.

\begin{tabular}{|c|c|c|c|}
\hline Population & Genetic distance & Nei identity & Geographical distance* \\
\hline BAC with CRO & 0.072 & 0.929 & $115 \mathrm{~km}$ \\
\hline BAC with FLA & 0.087 & 0.916 & $90 \mathrm{~km}$ \\
\hline BAC with PNA & 0.215 & 0.805 & $110 \mathrm{~km}$ \\
\hline CRO with FLA & 0.105 & 0.900 & $36 \mathrm{~km}$ \\
\hline CRO with PNA & 0.206 & 0.813 & $23 \mathrm{~km}$ \\
\hline FLA with PNA & 0.211 & 0.809 & $21 \mathrm{~km}$ \\
\hline
\end{tabular}

*Distance obtained from the Google Earth program. For abbreviations, see Table 1. 
T. speciosum may have genes and genotypes useful for genetic breeding of the species of the genus Theobroma, especially cocoa, because it is a great representative of the genus and has commercial value. Our results indicate that the ISSR molecular markers are efficient in detecting genetic variability in populations of $T$. speciosum. The technique is reproducible for the species and can detect polymorphisms. Most genetic variation was found between populations rather than within populations. Gene flow rate showed genetic isolation in these populations, which might be explained by the intensive forest fragmentation. Natural populations of $T$. speciosum present genetic diversity, and thus can be used in conservation and genetic breeding programs within the genus Theobroma.

\section{ACKNOWLEDGMENTS}

Fundação de Amparo à Pesquisa do Estado de Mato Grosso (FAPEMAT, Foundation for the Support of Research of the State of Mato Grosso), Conselho Nacional de Desenvolvimento Científico e Tecnológico (CNPq), and Universidade do Estado do Mato Grosso (UNEMAT) for the conductance of this research and the granting of scholarships for Undergraduate Research.

\section{REFERENCES}

Almeida CMA, Lima SEN, Lima GSA, Brito JZ, et al. (2009). Caracterização molecular de cultivares de cana-de-açúcar utilizando marcadores ISSR. Ciênc. Agrotec. 33: 1771-1776.

Alverson WS, Whitlock BA, Nyffeler R, Bayer C, et al. (1999). Phylogeny of the core Malvales: evidence from ndhF sequence data. Am. J. Bot. 86: 1474-1486.

Barth S, Melchinger AE and Lubberstedt T (2002). Genetic diversity in Arabidopsis thaliana L. Heynh. investigated by cleaved amplified polymorphic sequence (CAPS) and inter-simple sequence repeat (ISSR) markers. Mol. Ecol. 11: 495-505.

Batista EC, Telles MPC, Ramos JR, Soares TN, et al. (2008). Variabilidade Genética Intrapopulacional Utilizando Marcadores ISSR em Tibouchina papyrus. Simpósio Nacional Cerrado, Brasília.

Bekessy SA, Allnutt TR, Premoli AC, Lara A, et al. (2002). Genetic variation in the vulnerable and endemic Monkey Puzzle tree, detected using RAPDs. Heredity 88: 243-249.

Bittencourt JVM (2007). Proposta para conservação genética da Araucaria angustifólia. Pesq. Flor. Bras. 55: 87-93.

Brandão MM, Vieira FA and Carvalho D (2011). Estrutura genética em microescala espacial de Myrcia splendens (Myrtaceae). Rev. Árvore 35: 957-964.

Charters YM and Wilkinson MJ (2000). The use of self-pollinated progenies as 'in-groups' for the genetic characterization of cocoa germplasm. Theor. Appl. Genet. 100: 160-166.

Cidade FW, Souza-Chies TT, Batista LAR, Dall'agnol M, et al. (2009). Isolation and characterization of microsatellite loci in Paspalum notatum Flüggé (Poaceae). Conservat. Genet. 10: 1977-1980.

Cuatrecasas J (1964). Cacao and its allies A taxonomic revision of the genus Theobroma. Contrib. US. Nat. Herb. 35: 379-614.

Doyle JJ and Doyle JL (1987). A rapid DNA isolation procedure for small amounts of fresh leaf tissue. Phytochem. Bull. 19: 11-15.

Estopa RA, Souza AM, Moura MCO, Botrel MCG, et al. (2006). Diversidade genética em populações naturais de candeia (Eremanthus erythropappus (DC) Macleish). Sci. Forestalis 70: 97-106.

Excoffier L, Smouse PE and Quattro JM (1992). Analysis of molecular variance inferred from metric distances among DNA haplotypes: application to human mitochondrial DNA restriction data. Genetics 131: 479-491.

Excoffier L, Laval G and Schneider S (2006). Arlequin ver 3.01. An Integrated Software Package for Population Genetics Data Analysis. Computational and Molecular Population Genetics Lab (CMPG). Institute of Zoology, University of Berne, Berne.

Faleiro FG, Araújo IS, Bahia RCS, Santos RF, et al. (2002). Otimização de extração e amplificação de DNA de Theobroma cacao L. visando obtenção de marcadores RAPD. Agrotrópica 14: 31-34.

Ferreira ME and Grattapaglia D (1998). Introdução ao Uso de Marcadores Moleculares em Análise Genética. 3rd edn. Embrapa, Brasília. 
Figueira AVO and Cascardo JCM (2001). Marcadores Moleculares no Melhoramento. In: Melhoramento Genético do Cacaueiro (Dias LAS, ed.). FUNAPE, Viçosa, 385-438.

Hamrick JL (1982). The Distribution of Genetic Variation Within and Among Natural Plant Populations. In: Genetic and Conservation (Schonewald-Cox CM, Chambers SM, Macbryde B and Thomas WL, eds.). Benjamin Cummings, Menlo Park, 335-348.

Hamrick JL and Godt MJW (1996). Conservation Genetics of Endemic Plant Species. In: Conservation Genetics, Case Histories From Nature (Avise JC and Hamrick JL, eds.). Chapman and Hall, New York, 281-304.

Holsinger KE and Gottlieb LD (1991). Conservation of Rare and Endangered Plants: Principles and Prospects. In: Genetics and Conservation of Rare Plants (Falk DA and Holsinger KE, eds.). Oxford University Press, New York, 195-223.

Kumar S, Tamura K and Nei M (2004). MEGA3: Integrated software for Molecular Evolutionary Genetics Analysis and sequence alignment. Brief. Bioinform. 5: 150-163.

Lima CP (2002). Genética - O Estudo da Herança e da Variação Biológica. 6th edn. Editora Ática, São Paulo,

Lorenzi H (1998). Árvores Brasileiras: Manual de Identificação e Cultivo de Plantas Arbóreas Nativas do Brasil. 2nd edn. Editora Plantarum, São Paulo.

Matocq MD and Villablanca FX (2001). Low genetic diversity in endangered species: recent or historic pattern? Biol. Conserv. 98: 61-68.

Morden CW and Loeffler W (1999). Fragmentation and genetic differentiation among subpopulations of the endangered Hawaiian mint Haplostachys haplotachya (Lamiaceae). Mol. Ecol. 8: 617-625.

Nei M (1978). Estimation of average heterozygosity and genetic distance from a small number of individuals. Genetics 89: $583-590$

Oliveira AD, Barbosa MFP, Pimenta MAS, Braga RF, et al. (2008). Variabilidade genética de populações de fava d'anta (Dimorphandra mollis) da região norte do Estado de Minas Gerais. Rev. Árvore 32: 355-363.

Reis MS (1996). Dinâmica da movimentação dos alelos: subsídios para conservação e manejo de populações naturais em plantas. Braz. J. Genet. 19: 37-47.

Rossi AA, de Oliveira LO, Venturini BA and dos Santos SR (2009). Genetic diversity and geographic differentiation of disjunct Atlantic and Amazonian populations of Psychotria ipecacuanha (Rubiaceae). Genetica 136: 57-67.

Rossi FS (2007). Avaliação da Diversidade Genética Entre e Dentro Populações Naturais de Mauritia flexuosa (Arecaceae) no Município de Alta Floresta-MT, com Marcadores de ISSR. Monograph thesis. UNEMAT, Alta Floresta.

Silva CRS, Venturieri GA and Figueira A (2004). Description of Amazonian Theobroma L. collections species indentification and characterization of interspecific hybrids. Acta Bot. Bras. 18: 333-341.

Silva MC, Karasawa MMG, Vencovsky R and Veasey EA (2007). Description of Amazonian Theobroma L. collections species identification and em Oryza glumaepatula Steud. (Poaceae) avaliada com microssatélites. Biota Neotropica 7: $165-172$.

Whitlock MC, Ingvarsson PK and Hatfield T (2001). Local drift load and the heterosis of interconnected populations. Heredity 84: 452-457.

Wright S (1931). Evolution in Mendelian populations. Genetics 16: 97-159.

Wright SJ (2005). Tropical forests in a changing environment. Trends Ecol Evol 20: 553-560.

Yang SL and Meerow AW (1996). The Cycas pectinata (Cycadaceae) complex structure and gene flow. Int. J. Plant Sci. 157: 468-483.

Yeh FC, Yang RC and Boyle T (1999). POPGENE. Microsoft Windows-based Freeware for Population Genetic Analysis. Release 1.31. University of Alberta, Edmonton.

Zietkiewicz E, Rafalski A and Labuda D (1994). Genome fingerprinting by simple sequence repeat (SSR)-anchored polymerase chain reaction amplification. Genomics 20: 176-183. 